\title{
Analysis and Prospects of Development of Youth Business in the Republic of Sakha (Yakutia)
}

\author{
Anna V. Mikhaylova \\ Lidmila N., Popova* \\ Maxim Ammosov NorthEast Federal State University, Russian Federation \\ *Corresponding Email: mikanya23@mail.ru
}

\section{Doi:10.5901/mjss.2015.v6n6s7p337}

\section{Abstract}

The article is devoted to the problems and prospects of youth' business development in the Republic of Sakha (Yakutia). The article describes the results of a sociological research. The course on an innovative development of economy, the social, economic and political situation of the Russian Federation and the Republic of Sakha (Yakutia) in the context of an economic crisis of the past few years, as well as a number of other factors increase need for formation of new generation of the businessmen - young, dynamic, modern people that are capable of playing an active role in business, economy and in development of a society. Young businesspersons are defined by high mobility, activity, 'initiativeness', high speed of adaptability and innovation. The key problems disturbing the formation of business processes among young businessmen of the Republic of Sakha (Yakutia) are defined in the course of research. The social portrait of the businessman is 'drawn', practical recommendations on support of youth business and main antecedents for entrepreneurship in the Republic of Sakha (Yakutia) are developed.

Keywords: state business support, social characteristic of business, youth business

\section{Introduction}

Relevance of studying the development issues of business, including run by youth, is defined by the role it plays in the framework of society and the state. Besides, studying of process of inclusion of young people to the sphere of business, process of formation of young businessmen, being a separate social class, which differs in high mobility, activity, adaptability, flexibility, innovation and creativity of thinking is an important sociological research objective. Development of SMEs of current interest for all regions of Russia, including the Republic of Sakha (Yakutia). In the republic, the following relevant documents are elaborated: The Strategy of development of small and average business for 2011 - 2020 (The Decree (2011), The official information portal (2015), The Strategy of development of the Republic of Sakha (2015), The order of the government of the Republic of Sakha (2014)) were realized, information portal of support of business was created. The Ministry of business and development of tourism of the Republic of Sakha (Yakutia) has declared the year 2015 as the year of business in the largest subject of the Russian Federation that once again confirms the big social importance and considerable attention to development of business on behalf of the state.

Over the past few years, the Republic has undergone an extensive developed and turned into a region with great opportunities for investors. Given its demographic and social stability, its highly educated young workforce and economically active population, as well as rich natural resources, Yakutia has strengthen its position as the economic driver in the Far Eastern Federal District. The Republic is among the leading regions in the Far Eastern to set a long-term development policy - the 'Plan for integrated development of the Republic of Sakha (Yakutia) up to 2020'. This plan closely relates to the key national industrial strategies: the General Configuration Plan of Electric Facilities in the Russian Federation through to 2020; the Energy Strategy of the Russian Federation; the Transport Strategy of the Russian Federation through to 2020; the Program for the Creation of a United Extraction and Transportation System for Gas and Gas Supply in Eastern Siberia and the Far East (exploration the exports of gas to China and other Asia-Pacific countries), as well as the Railway Transport Development Strategy of the Russian Federation through to 2020.

Scholars in Russia and around the world consider business through processes of change of social structure, formation of middle class, formation of an enterprise layer, economic socialization of youth, development of the state support of business. Referential publications of sociologists, economists, historians on this matter are the research of Arkhipova (2012), Kozyrev (2015), Arkhipova (2012), Goliusova (2011), Konstantinovsky et al. (2014), Mikhaylenok \& 
Lyublinsky (2015) to name just a few. The foundation to sociological studies of business in the region was laid by research of department of the right and sociology of institute of humanitarian researches of academy of Sciences of the Republic of Sakha (Yakutia), which is carried out in Yakutsk and Neryungri. However, it should be noted that some aspects of business remain poorly studied. Most of researchers (Abramova, 2000; Goliusov, 2011; Kozyrev, 2015; Mikhaylenok \& Lyublinsky, 2015; etc.) emphasize business development as defining level and quality of life of the population, a social and economic condition of society. According to Kozyrev (2015, p.15), "business is one of the main factors of economic development of the country".

In the research of Dzhekobs \& Charles (2010, p.225), it is noted that "people generally don't realize all importance of businessmen and their activity". All material benefits are a result of action of businessmen and the state. As generally known, "the purpose of each businessman - obtaining benefit, profit". To get this profit, businessmen fill all niches of a social system that on their goods or service there was a demand, businessmen satisfy requirements of society, our, general society. All that we now see, use, stand on is a merit of businessmen and the state. We suggest that Dzhekobs and Charles (2010, p.17) are right, noticing that "The state in itself can provide life of the citizens, but with business, we live in much more comfortable conditions". As it is stated in the Strategy of development of small and average business in the Republic of Sakha (Yakutia) for 2011 - 2020, the business is a strong factor for evolution of economic culture and culture of managing of the organizations, stimulates performance of innovative function of these social mechanisms. We are agree that a basis of enterprise behavior are individuals, namely the aspirations of individual persons to realization of the economic interests (Mikhaylov, 2015). A large number of opportunities for such activity is provided by social and economic systems, which are based on market capitalist societies.

The analysis of standard and legal sources enable to draw conclusions that the state by means of laws tries to keep development of business in Russia, to define the status of all subjects of business, on the other hand does not define at the legislative level of the category 'youth' and 'youth business'. Thus, the federal legislation does not allocate young businessmen in separate category in this regard, they get the state support in accordance with general practice with other subjects of small business. Despite the various case studies and the empirical evidence on such phenomena, it is still necessary to provide a conceptual framework to a category of 'youth' and 'youth business'. Thus, the study aims to alienate factors of development of youth business and to develop practical recommendations about its development in the Republic of Sakha (Yakutia). Object of research is business, a subject business activity of youth in the Republic. The empirical base of research includes federal and republican Concepts and Programs in the sphere of business, results of the conducted research.

\section{Methodology and the Results of the Research}

Research hypothesis is as follows:

- Young businessmen are poorly informed on support which is given by the state and the republic to businessmen;

- Young businessmen open business in the trade and entertaining sphere more often;

- Young businessmen at the beginning of the activity face a problem of documentation and reporting more often;

- Rather young age of the businessman negatively affects on opening and business.

- In research we used the following methods. The first is an interview by experts. The second method questioning. The third is an analysis of the official documents and sources of the Republic of Sakha (Yakutia) devoted to youth business. Next method was survey.

The first stage of research included interviews of experts. An expert of the first interview was an accountant, a professional consultant of' the 'Center of support of business of the Republic of Sakha (Yakutia)'. Interview was conducted in Yakutsk at office of the center on February 10, 2015. During interview, the audio recording was conducted. Interview took place in the form of conversation in a separate office. Answers to the interesting questions were received: An expert of the second interview was a representative of Chamber of Commerce and Industry of the Republic of Sakha (Yakutia), member of Presidium of Board. In the Republic of Sakha (Yakutia) the Chamber of Commerce and Industry is the largest non-state organization giving help to businessmen of the region. Interview took place in office of Chamber of Commerce and Industry. Interview registered in a notebook. Interview was conducted in the closed office room where there were four workplaces, however during interview in an office only one employee worked.

The second stage was a questionnaire. Survey took place in Yakutsk, at office 'Center of support of business of the Republic of Sakha (Yakutia)' from January 18, 2015 to February 10, 2015. Selection was continuous. The 
questionnaire was distributed to all who approached in 'The center of support of business of the Republic of Sakha (Yakutia)' behind the solution of any question. There were 95 full questionnaires, 82 of which - already acting businessmen, are 13 young, beginning businessmen. Age of respondents from 25 to 35 years. As well as an additional survey held on-line using SURVIO.COM website. A total of 67 acting businessmen aged till 35 years inclusive took part in poll. The questionnaire was provided only to participants of community 'Business Horde'. The community 'Business Horde' exists since 2013 and totals about 350 participants, unites the acting businessmen and those who is going to open the business. 'Business the Horde' often holds seminars, meetings and the training courses on business, as on a free, and paid basis. Survey was conducted from May 30 to June 12, 2015.

Additionally, the following documents have been analyzed: Development of indigenous ethnic groups of the North of the Republic of Sakha (Yakutia) to 2020 year, Official site of NIU of Higher School of Economics (2015), Research VCIOM (2013): Business climate in Russia in 2013, Strategy of development of small and average business in the Republic of Sakha (Yakutia) for 2011 - 2020 (2011-2020), The decree of the President of the Republic of Sakha (Yakutia) (2011), The official information portal of small and average business Republic of Sakha (Yakutia) (2015), The official information portal of small and average business Republic of Sakha (Yakutia) (2015), The order of the government of the Republic of Sakha (Yakutia) (2014), The static bulletin No. $302 / 549$ (2011).

\section{The Results of the Research}

The purposes and tasks of the Center of support of business is the help to the businessmen both acting, and beginning. Center advises all addressed citizens, gives financial support and conducts information and explanatory work. The center gives financial support in a type of subsidizing and micro financing. On average in a month to the hot line of the center about 500 citizens of the republic address. Young businessmen are girls and the young man till 30 years. The beginning young businessmen of the Republic of Sakha (Yakutia) address for consultation in the field of taxes, reports, control and supervisory authorities. The acting young businessmen of our republic specify under the resolution on tax holidays. In the federal law of the Russian Federation, it is specified that regions can choose on what kinds of activity there will be tax holidays. In the federal law, the individual entrepreneurs registered for the first time who apply the simplified system of the taxation or patent system of the taxation in production, social, scientific, spheres - can apply a zero rate. All information on educational programs, seminars, trainings, changes in the legislation, can be retrieved from the official site of center www.b14.ru, having also called to the hot line, or to be suitable in office for direct consultation. All seminars held by the Center of support of business of the Republic of Sakha (Yakutia) are free of charge.

At the end of conversation, the expert stated recommendations, councils to young businessmen of the region. First, to choose a field of activity. Secondly, to estimate the level of competence. Thirdly, to study the market and financial opportunities, to make the business plan. Fourthly, to approach behind consultation in the center of support of businessmen of the Republic of Sakha (Yakutia). Chamber of Commerce and Industry - the leading non-profit, non-state organization in Russia which is engaged in creating favorable conditions for business in any places, including in the Republic of Sakha (Yakutia). The chamber unites on a voluntary basis businessmen and the enterprises which are engaged in trade and rendering of services, production. The purpose of chamber - the protection of enterprise interests, assistance to business operating in a certain territory according to the charter. Mission of Chamber of Commerce and Industry of the Republic of Sakha (Yakutia) - 'To be an independent and competent vote of business people of the Republic of Sakha (Yakutia)'.

The chamber establishes connection with officials of the Republic of Sakha (Yakutia), conducts the closed negotiations on behalf of enterprise community of Yakutia, gives extensive and full help on the interesting questions, such as the organization and conducting business activity. Together with the government of the country discuss and offer the state laws, amendments on coordination. The Chamber of Commerce and Industry of the Republic of Sakha (Yakutia) is one of the main extra state organizations supporting businessmen. A main type of support that is given by Chamber of Commerce and Industry of RS (Ya) to businessmen is:

- Information consulting support, help in writing and implementation of the business plan, marketing and tutorial support. Informing businessmen on changes in legislative bases of the Russian Federation, on grants and subsidies.

- Support of in finding of partners in all Russia and beyond its limits. Establishment of useful political and economic contacts with the foreign organizations.

- Support of in examination and certification of goods, production and raw materials. Research of goods in vitro.

- Carrying out of the training seminars and courses. Training is provided both for the acting subjects of small 
business, and for those who is only going to open the business.

- Granting of the help in creation and ensuring legal protection of goods and intellectual property. Granting of services of the arbitration court and many other things.

The Chamber of Commerce and Industry has centuries-old history. Nowadays, the chamber has the status of the international organization, totals more than 10000 chambers worldwide. In Russia 157 city and regional chambers, 16 foreign representations of Chamber of Commerce and Industry of the Russian Federation and 9 mixed chambers are. In Chamber of Commerce and Industry of the Republic of Sakha (Yakutia) 340 members - the enterprises of the Republic of Sakha (Yakutia) are registered. The Chamber of Commerce and Industry of the Republic of Sakha (Yakutia) carries out two main functions: 1. Interaction with government bodies the purpose of creation of optimum conditions for conducting business activity, and 2. The serving function where help to the members is given, various services are also provided.

At the end of conversation, the expert also stated the wishes and recommendations that the organization invites everyone, pupils and student's youth to participation and cooperation.

The conclusions are made that the most significant support of young business in the Republic of Sakha (Yakutia) is the state renders. The state support of business activity is directed first, on legal and information support of business, secondly, on financial support of business.

The legal and information support is necessary to be provided to the organizations created with the assistance of the state and working for the benefit of business development:

The all-Russian association of businessmen "the Support of Russia" which basic purpose is protection of the rights and interests of businessmen, fight against corruption, creation favorable "business of climate" in the Russian regions.

The representatives by the rights of businessmen acting in many regions of our country including to the Republic of Sakha (Yakutia);

The Chambers of Commerce and Industry $(\mathrm{CCl})$ which are created on the basis of membership for realization of the purposes and tasks connected with granting interests of the Russian businessmen in the relations with authorities. Those are the Chamber of Commerce and Industry of Russia, Chamber of Commerce and Industry of the Republic of Sakha (Yakutia);

Associations of employers which are urged to protect interests of employers in the sphere of the social and labor relations;

Non-profit organizations - the Centers of development of business created with the assistance of the state and which are carrying out information, consulting, legal, accounting and other aid to businessmen. These centers function in many cities and settlements of our country. So, in the Republic of Sakha (Yakutia) function "The center of support of business of the Republic of Sakha (Yakutia)", "Business the Incubator" and so forth.

The second type of support is the state financial support of business. Many authors specify that SMEs participating programs of the state support should not only be those working in the sphere for few years, but the beginning businessmen who are only going to register the activity (Abramova, 2000; Arkhipov, 2012; Kozyrev, 2015; Konstantinovsky et al., 2014). The main types of financial state support of business operating in the territory of the Russian Federation:

Subsidies (grants) for opening of own business, to 300000 rubles.

Granting loans to subjects of small and medium business to 1 million rubles under $8 \%$ per annum, for the term of no more than 1 year;

- Subsidies to subjects of small and average business to 1 million rubles for compensation of costs of acquisition of the equipment on production heat of energy and the electric power by use of alternative sources; Support of export-oriented subjects of small and medium business (though it is also not financial). Within this support you will be tried to be helped with search of foreign partners for the conclusion of contracts of export and import of production.

- Grants on opening of own business is a free aid to the beginning businessmen from the state. The subsidy size within this support not big - to 300 thousand rubles, for innovative business - to 500 thousand rubles.

Control of development of business in the republic is exercised by the Ministry of affairs of business and development of tourism of the Republic of Sakha (Yakutia). The year of 2015 is declared in the republic - year of business in this regard, the government accepted a number of the measures promoting development and public awareness of small and average business, such as economic support, decrease in interest rates for the credits, loans, realization of grants and many other things.

The majority of respondents started being engaged in business activity aged from 20-29 years. Perhaps, this age 
is explained including by that young people in have yet no family that needs stable earnings. Also, it is possible that upon completion of higher education institutions the youth seeks for realization of the ideas and projects.

The main reasons motivating young people to occupation with business - desire to have the high income, financial independence, financial freedom, opportunity to do favorite thing, to work for the good of the homeland, to develop culture and heritage, to provide to the family a worthy standard of living, to expand the business to the All-Russian or international scale and so forth. Business activity of youth extends almost on all types of economic activity, however unlike all businessmen, young businessmen choose business in the form of small business or in the sphere of entertainments. Young businessmen of Republic of Sakha (Yakutia) are poorly involved in the production sphere, they are more often involved in the sphere of creation of software, cell phones applications, in a services sector in the youth focused and entertaining sphere such as a snowboard, a paintball, art coffee, fitness services, services in the healthy nutrition (HN) etc. From 95 respondents who addressed in TsPP RS(Ya) 82 (86.32\%) respondents have the operating business (fig. 1).

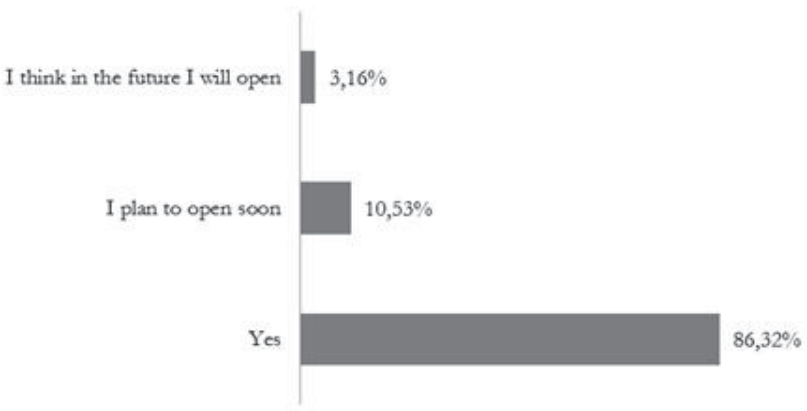

Figure 1. Answers to a question "Are you running an operating business?"

From all interrogated respondents of TSPP - 82\% - individual entrepreneurs, 18\% - founders of limited liability company. According to businessmen, the developed political and economic situation in the country it isn't strong, but I influenced business in RS (Ya) (fig. 2). Practically all young businessmen first of all need financial support, on the second place information and consulting support, on the third place educational and property support.

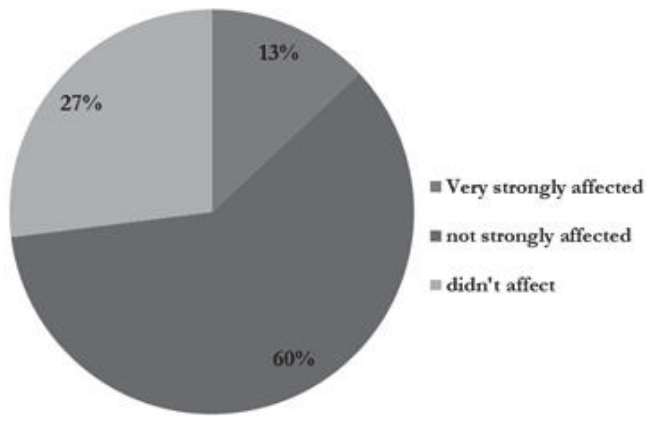

Figure 2. Influence of a social and economic situation in the world and in the Russian Federation on entrepreneurial activity

According to respondents (young businessmen), the state and the government Republic of Sakha (Yakutia) poorly supports youth. Questioning enables to reveal and analyze difficulties which young businessmen of Republic of Sakha (Yakutia) met. On the first place financial difficulties (shortage of current assets, the initial capital), on the second - need to hand over reports (lack of consulting support on the correct filling of reports, about possibility of reminders from supervisory authorities on terms of delivery of the reporting, about automation of process of delivery of reports), on the third place corruption barriers when opening the business (fig. 3). 


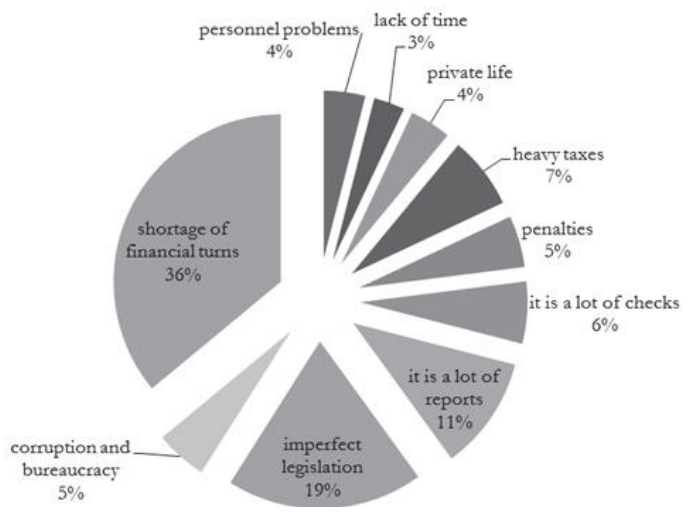

Figure 3. The analysis of difficulties in business activity in RS(Ya)

The 67 acting businessmen aged up to 35 years inclusive, from business community 'Business Horde' for the purpose of drawing up a social portrait of the young businessman of RS (Ya) were interrogated. Most of the interrogated businessmen, enter into age group of $25-29$ years and are males, have the operating business. Young businessmen of Yakutia estimated support of the state on 3.8 points from 10. Thus $10 \%$ of respondents indicated intervention of government bodies in activity of individual entrepreneurs and in excessive control in the form of reports. Most of respondents have the higher education, a quarter of businessmen have secondary vocational education. It means that the modern young businessman - the person with education. However, 21 persons from respondents do the business that is not connected with the profession. Besides, respondents consider that now to be the beginning young businessman in Yakutia business difficult. By results of poll the social portrait of the young businessman of the Republic of Sakha (Yakutia) looks as follows: the male young man, at the age of 25-30, having the higher education, active, initiative, single, ready to risk, the having initial capital (as a rule, it is family support).

Many respondents consider that youth business in the republic will gain active development in case support of small business from the state is given, there will be a decrease in taxes, trainings, master classes and seminars in which famous and successful representatives of business, etc. will participate will be organized. It is suggested that it is possible to allocate the main problems interfering development of youth business:

1. Social spirit of young people. In the youth environment often there is no readiness to take the risk, to create something new, there is no spirit of business.

2. Perception society of businessmen. Among young people businessmen are perceived, as people who should overcome constantly difficulties, but not as the businessmen striving for success.

3. Level and maintenance of educational programs. Traditional Russian educational institutions give bases of economic knowledge, thus don't form incentives and behavioural competences without which successful business activity is impossible.

4. Weak support of businessmen during opening of the business, the high level of corruption when receiving the state support in a type of grants and subsidies.

5. Lack of consulting support when filling reports, heavy taxes.

\section{Conclusion}

Experts and results of poll confirmed our hypothesis that young businessmen of the region are poorly informed on support of business from the state. Business activity of youth extends almost on all types of economic activity, the emphasis is placed on SMEs in the sphere of entertainments. The interrogated young businessmen chose a form of the managing enterprise - individual business. It is possible it means that it is more convenient to young businessmen to choose this economic entity because it demands smaller documentation and the reporting. However, a level of responsibility 10 times more, than at limited liability company. An overwhelming number of respondents noted that the difficult political and economic situation in the country influences business; however, losses make insignificant part. As many as $73 \%$ of the interrogated businessmen business partially or is completely connected with external market 
condition. Young businessmen of the region first of all need financial support, and then the information and consulting.

In the Republic of Sakha (Yakutia) the Chamber of Commerce and Industry - the leading non-profit, non-state organization in Russia which is engaged in creating favorable conditions for business in any places works, including in the Republic of Sakha (Yakutia). The chamber unites on a voluntary basis businessmen and the enterprises which are engaged in trade and rendering of services, production. The purpose of chamber - the protection of enterprise interests, assistance to business operating in a certain territory according to the charter. Mission of Chamber of Commerce and Industry of RS (Ya) - 'To be an independent and competent vote of business people of the Republic of Sakha (Yakutia)'. The chamber establishes connection with officials of the Republic of Sakha (Yakutia), conducts the closed negotiations on behalf of enterprise community of Yakutia, gives extensive and full help on the interesting questions, such as the organization and conducting business activity. Together with the government of the country discuss and offer the state laws, amendments on coordination.

The main reason for young people open own business is the desire to earn a lot of money. In addition, young businessmen do not wish to work all day long, to pension. The desire to work only for itself and to do favorite thing also is the widespread answer among participants of poll. Young businessmen open the business with the purpose to earn a lot of money, also to find financial independence, financial freedom, to do favorite thing, to work for the good of the homeland, to develop culture and heritage, to provide the children and relatives with a worthy standard of living, to expand the business to the All-Russian or international scale and so forth. Although, young businessmen at the beginning of the activity are faced financial difficulties, a problem of unstable profit, and complications with documentation, the reporting and allowing and prohibitive documents. Research showed that for development of business among youth of Yakutia it is necessary to strengthen financial support, to reduce taxes at an initial stage, to provide PR-actions, trainings, master classes and seminars.

On the basis of the received results, it is possible to offer the following recommendations:

- To strengthen the state support to young (beginner) businessmen in RS(Ya);

- To organize the training and consulting seminars, for young businessmen;

- To inform more businessmen on TsPP RS (I), the directions of its activity, and also those organizations which carry out support of young businessmen.

Furtheron, the system approach to studying of this phenomenon, results of complex sociological researches can promote formation in the republic of effective strategy of development of business in the Republic of Sakha (Yakutia).

The vector of social and economic development of economy of the Republic of Sakha (Yakutia) is put in such strategic documents as the Scheme of complex development of productive forces, transport and power of the Republic of Sakha (Yakutia) till 2020 and its project till 2030, the Forecast of social and economic development of the Republic of Sakha (Yakutia) for 2011 and for the period till 2013, the Program of development of the competition of the Republic of Sakha (Yakutia) for 2010-2012, Program speech of the President of the Republic of Sakha (Yakutia) before the State Meeting (II Tumen) the Republics of Sakha (Yakutia) on June 17, 2010 for 2010-2015, etc. In all called documents the important part is assigned small and to average to business. The territorial structure of economy of the republic provided by the Scheme of complex development of productive forces, transport and power forming six social and economic areas formed on the terms of public-private partnership predetermines participation and development of small and average business, as basically, and the serving branches. In this regard in the territory of the republic the Scheme allocates the main priority development areas (PDA): PDA No. 1 'Central Yakutia' within which creation of transport and logistic knot, a scientific and educational complex, development of information technologies, tourism, the processing productions is supposed (in particular, jeweler and lapidary production); PDA No. 2 'South Yakutia' - which primary branches of specialization will become production and enrichment of coal, production and processing of iron ores, uranium ores, gas chemistry, chemical production, wood processing, thermal and hydropower, production of non-ferrous metals; To PDA No. 3 'Western Yakutia' which will specialize on - oil and gas production, to the oil and gas processing and helium industry and production of diamonds; PDA No. 4 'Northeast Yakutia', - which will be focused on production of non-ferrous and rare-earth metals.

World experience shows that all countries that made technological and economic breakthrough, anyway, built within the country the effective system of development and commercialization of scientific development in many respects based on development and support of sector of the small and average business, which is the most dynamic factor of economic growth. Therefore, the most attractive to small business is development of innovative technologies for the investment projects realized in the territory of the republic. The state and large business are interested in modernization, as introduction of innovative development is necessary for development and diversification, achievement of sustained economic growth and competitive labor productivity level. Possibly to achieve goals due to development of youth business. 
The study inspires confidence in the prospects of development of youth entrepreneurship in the Republic of Sakha (Yakutia). There are seven reasons that prove this point: unique geographical location; developed infrastructure for the support of small and medium-sized enterprises; high level of social and economic development; stable credit rating; convenient conditions for investment activity; significant reserves of natural resources; and a significant business development potential for the extraction and processing of mineral and fossil resources.

\section{References}

Abramova, S.V. (2000). Business in the Republic of Sakha (Yakutia). In: Republic of Sakha (Yakutia): Way to the sovereignty. V. N. Ivanov (ad.). Yakutsk, p. 322 pages.

Arkhipova, V.S. (2012). Professionalizing through social business: creation of new competences of the sphere of theatrical pedagogics. World of Russia. Sociological Researches journal, 3, 80-99. [on-line] http://www.isras.ru/socis.html

Chiryaev, G.I. (2006). Development of productive forces of the Republic of Sakha (Yakutia). Republic economical conference - Yakutsk, p. 1-17

Development of indigenous ethnic groups of the North of the Republic of Sakha (Yakutia) to 2020 year (2007). Research of problems indigenous peoples of the North of the Siberian Branch of the Russian Academy of Science. Yakutsk.

Goliusova, Yu.V. (2011). Problem of self-employment of youth in the conditions of the region. Theory and practice of social development. Sociological Researches journal, 3. [on-line] http://www.isras.ru/socis.html

Haidar, J.I. (2012). Impact of Business Regulatory Reforms on Economic Growth. Journal of the Japanese and International Economies, 26(3), 285-307.

Jacobs, C.S. (2010). Neyromenedzhment. Why the motivation doesn't work with method of a carrot and stick.

Konstantinovsky, D. L., Voznesenskaya, E.D., \& Cherednichenko, G.A. (2014). Youth of Russia at a turn of the XX-XXI centuries: education, work, social well-being. Moscow: TsSP and M.

Kozyrev, P.M. (2015). Small business in Russia: daily problems and difficulties of development//Economic and social changes: facts, tendencies, forecast. Sociological Researches journal, 1(37), 43-58. [on-line] http://www.isras.ru/socis.html

Mikhaylenok, O.M., \& Lyublinsky, V.V. (2015). A consent in society as a condition of development of Russia. Release 4. An inequality in modern society. Political and social aspects: collection articles. Moscow: Institute of sociology of the Russian Academy of Sciences.

Mikhaylov, A.S. (2015). Conceptualizing international cluster. Mediterranean Journal of Social Sciences, 6 (3), 11-18.

Official site of NIU of Higher School of Economics: [Electronic resource]: Retrieved June 10, 2015 http:/lecsoc.hse.ru/2000-11/26591426.html

Official site of the Ministry of affairs of business and tourism of RS (Ya): [Electronic resource] Retrieved June 10, 2015 from www.minpred.ru.

Research VCIOM (2013). Business climate in Russia in 2013. [Electronic resource]. Center of humanitarian technologies. - 2013.06.04. - Retrieved June 10, 2015 from http://gtmarket .ru/news/2013/06/04/5968

Shchenina, O.G. (2012). State policy, priorities and strategy of reforming of the social sphere//Russia: tendencies and prospects of development. Year-book. Vyp. 7. Part 2. Отв. edition. YU.S. brewers - M.: INION of the Russian Academy of Sciences. 2012. Page 533-538.

Strategy of development of small and average business in the Republic of Sakha (Yakutia) for 2011 - 2020. Retrieved June 01, 2015 http://www .sakha.gov.ru/node/10791

The decree of the Head of the government of the Republic of Sakha (Yakutia) About the Plan of measures on carrying out Year of business in the Republic of Sakha (Yakutia) and Organizing committee for preparation and carrying out Year of business in the Republic of Sakha (Yakutia) of December 12, 2014 No. 201-RG//http://www.mfcsakha.rulfiles/2015b-plan.pdf (31.05.2015)

The decree of the President of the Republic of Sakha (Yakutia) (2011) "About a state program of the Republic of Sakha (Yakutia) "Development of business in the Republic of Sakha (Yakutia) for 2012-2016" of October 12, 2011 № 980 Retrieved June 01, 2015 from http://docs .cntd.ru/document/473509629

The official information portal of small and average business Republic of Sakha (Yakutia) (2015) Retrieved June 05, 2015 from http://b14.rul

The order of the government of the Republic of Sakha (Yakutia) (2014) of 01.10.2014 1344-Z N 241-V "About modification of the Law of the Republic of Sakha (Yakutia) "About development of small and average business in the Republic of Sakha (Yakutia)" (RS(Ya) of Z N 242-V is accepted of 01.10.2014 by the resolution GS (II Tumen)) Retrieved June 05, 2015 from http://base.consultant.ru/ regbase/cgi/online.cgi? req=doc; base=RLAW249; $n=46405$

The static bulletin No. $302 / 549$ (2012). The main indicators of activity of subjects of small and average business in the Republic of Sakha (Yakutia) for January and September, 2011. Yakutsk.

Turenko, T.A. (2010). Small business and its role in a sustainable development of economy. News of Irkutsk state economic academy, 5 , 223-227. 